\title{
MUNICIPAL MARKETS IN THEIR RELATION TO THE COST OF LIVING
}

\author{
By Cyrus C. Miller,
}

President of the Borough of the Bronx; Chairman of the Mayor's Market Commission, New York City.

When the farmer's crop is grown, his work is only half done, for, quite as important to him as successful production, is successful marketing. He must determine the best time and place and method of selling. Not many years ago farm produce was taken to market by the farmer himself in his own wagons. Often he became salesman and disposed of his goods to his customers, who were sometimes dealers, but more often housewives. Every community depended for the most part for its food on the products of its vicinity.

All this has changed. Large cities no longer can subsist upon suburban supplies. Their food is brought from the four corners of the earth through all the seasons of the year; native products form but a small part of the supplies. The farm wagon is a vanishing view; it has given place to the railroad, steamship and steamboat. Householders in the cities no longer lay in their winter stock in the fall, but must depend on the daily supply brought from other climates and from the cold storage warehouses. Marketing has changed from the simple operation of early days to a most complicated process involving the passing of the goods through the hands oftentimes of the railroad, or other carrier, the receiver, the wholesaler, the jobber, and the retailer. Scientific and consequently economic marketing requires the coördination of all these members in the process of distribution so as to convey the crop from the producer to the consumer with the least delay and consequent spoilage, with the least handling, and the least cost. The main problem in modern marketing is one of efficient distribution.

The first move in the process lies with the producer. He must determine what market will be best for his goods, and whether it is better to send them at the time of production or store them until such time as the market may require them. It is obvious that perishable 
products, such as berries, peaches and asparagus, must be sold at once, so with them the question is to what market to send them and how to get them there as quickly as possible. Other products semi-perishable by nature, such as butter and eggs, may be kept in cold storage; others, like potatoes and apples, may be kept in cooled storage for future delivery. To avoid gluts in the market is a difficult matter. At present the shipper has comparatively little information on the subject and he must take chances in sending to any market.

The day probably will come when the federal government will issue daily market reports based on the daily reports from the large cities, just as it issues weather reports, stating the quantity of produce in the market and on the way. This will give the shipper some information whereby he can decide where he shall send his crop. The railroad companies have done good work in enlarging the number of shipping points and thus helping producers to get better prices by increasing the demand for their products and at the same time supplying places with crops they could not get without such help. The service which the railroads perform in assisting in the distribution of crops through the country was so well stated in some testimony given by Mr. J. D. Remington of the New York Central Railroad, before the mayor's market commission of New York City recently, that I quote what he said, in part:

I have for a good many years been associated with the perishable fruit and vegetable business of the country for both the Pennsylvania Railroad and the New York Central. I have been engaged more or less in the development of methods in this respect-in going into communities and pointing out to them how they might in all points benefit themselves and their own community by development of crops and diversifying crops that in some sections were neglected; where the Almighty in His wisdom had provided the facilities for rotation of crops and there seemed to have been a missed cog in the wheel in those particular places. I have endeavored to show them how they could drop in some commodity and raise it which would result in making a continuous rotating movement out of that commodity. I have run onto some interesting things in connection with that.

Take Long Island, for instance, with its cauliflower industry. There is a highly satisfactory climate and there is the salt air passing over there that enables them to produce a wonderful cauliflower. But four weeks earlier, in Cape May County, with the salt air from the ocean blowing directly over the same soil, they can produce the same crop. By producing it there, the season is just so much longer. The result is the doubling of produce and the doubling of the season. We did a good bit of that kind of work. 
We did a good deal of development work and we used to bring in the seed houses and the men familiar with that part of it. Of course, the railroads, with their increased speed and increased refrigerating facilities have made the seasons very much longer. For instance, there was a time on strawberries when the season for them was only six weeks long. That was all the time that we could get strawberries. Now you start in in February with the Florida strawberries and you have strawberries until the middle of the next July from northern New York. This works two ways-to the advantage of the producer and the consumer and also to the advantage of the transportation company. In July the same cars after refrigeration are taking berries south from northern producing states that in May were taking them from North Carolina north to those same points. The methods used and the increased speed and the entire situation make a very interesting study.

Distribution, the distribution of a crop from any large growing section, is interesting. The word covers a lot and regulates to a certain extent this matter of the cost of high living. The producer naturally must make money; if he doesn't, he won't produce. The railroads are anxious for the grower to make money; the more he makes, the more his growth will be; the greater his growth, the greater the quantity to be shipped; the greater the quantity shipped, the more money there is to the carrier, and naturally, the better the price to the consumer.

The railroads do not get credit for any part they take in the development of the agricultural sections. The average grower or farmer thinks that the railroad company is after his hide and that they will get it wherever they get a chance, and a great many things we do that seem arbitrary to them are really entirely helpful to them. I remember having been the pioneer in the North Carolina Strawberry-growing belt. I went in there a number of years ago and found that 400 cars of strawberries from North Carolina were distributed to only 12 markets. That then was the largest year they had ever had. I happened to be in Wilmington, North Carolina, at a meeting of the directors of the North Carolina Fruit Growers and Truck Growers Association. When asked by them whether I had any suggestions to make to better their condition I told them I did not come up there to run their business but that the thought occurred to me that they did not give their crop a wide enough distribution. I told them that 400 cars to 12 markets was not enough markets. You can glut New York, just as easy as Binghamton, New York, by sending too much fruit there, and when too much fruit goes to any market the prices are bound to go down to a point where money is lost by everybody. I told them to send their goods to more markets and then and there we took up the task of increasing the distribution. Nine years after that, when I left the employ of the Pennsylvania Railroad, remembering when I first met them that they shipped 400 cars to 12 markets, I had the pleasure of knowing that that year they shipped 3200 carloads to 82 different markets. That was a pretty good result and it was entirely due to coöperation on the part of the societies, the railroads, and everybody to make a proper distribution. The result was entirely satisfactory to the growers and to the consumers and to the carrier. Everybody was benefited. But 82 markets were not enough. We had 3500 carloads of peaches out of western 
New York this year on our rails. We sent them to 275 markets. That is distribution.

We suggest markets and assist in creating them to the extent of even inducing men to go into the business. Of course, the shipper has his own option as to where they shall go. I remember one place where in a good city in our eastern states they had no commission men. The city was big enough to take a carload of North Carolina berries every other day but there was no one there to handle them. I went to that city. I went to a wholesale grocer and asked him why he could not go into that business. I said, "Here is good money for you, and there is no reason why you cannot pick up a couple of thousand dollars this year right on that." He said, "That is out of our line." I said, "Is it any more out of your line than to handle cold storage products in connection with a butcher business?" He commenced to think. He said, "How can we do that?" I said, "There are several ways; you can buy the goods outright or you can receive them on consignment and sell them for a commission. Your city ought to be on the map and ought to be a receiving point." He got on the map, and that city has taken anywhere from three to five cars a week of North Carolina strawberries every year since that time, thanks to the railroad for suggesting the way to the receiver and to the shipper-but the railroad got no thanks for taking that part in it.

We have more of a problem to solve assisting in the development of the agricultural regions than the average person understands. You have read of our farm trains. They are the educational trains that we run. It was my duty as special agent-I should say, it was my privilege and pleasure as special agent-to be sergeant at arms and conductor of those five farm trains run through agricultural sections. And it was indeed a pleasure to hear the Cornell experts and others explain to the farmers things they did not know and listen to the questions by persons, about what they wanted to know. That was most interesting. It cost us a lot of money, but it was money well invested. It was sowing the seed. We commence now to perceive where benefits are coming from that and the communities are bettered.

If a producer can be assured of a good market he is likely to produce more goods. If he finds he has made money on a ten-acre peach patch this year, he is induced to put in five acres more next year if he thinks it will pay him to do so; but if he lost money on them this year he would not be so apt to increase his acreage. A good steady-priced market, the price being such as to enable the producer to realize a reasonable profit is of course the ideal thing. Nobody expects in these days to get rich on a farm the first year but they do not want to lose money on it.

Farmers who complain that they do not receive fair prices often do not realize that by failing to grade and pack their goods properly they make it necessary for the middlemen in the market to unpack, sort, grade and repack them, all of which costs money and results in delays and spoilage. Customers such as hotel men, fruiterers and retailers look for the particular kinds and grades their trades require. 
In order to be sure of buying what they need, they go to a jobber who either buys such supplies already graded by the farmer or buys such as he can in the market, takes it to his warehouse, and sorts, grades and packs it himself. Some of the produce is packed fraudulently as well as ignorantly, which tends to reduce the prices given for the whole supply to the low prices of the inferior goods. The honest farmer suffers for the dishonest one. Because of lack of confidence between buyer and seller the whole trade, both as to quantity bought and prices paid is conducted on a minimum basis. In a recent article in a magazine, the writer told of asking an old fruit-grower the question, "What is the farmer's worst enemy? Is it frost, flood or drought? Is it, weeds? Is it animal disease, plant disease or insect pests? Or, as some say, is it the oppressive middleman?" The answer was, "It isn't the codling moth or the clinchbug, the smut or the cutworm, the cattle tick or hog cholera, the untimely frost or withering drought, or even the middleman that costs the farmer--at least my kind of farmer - the heaviest tolls in unrealized rewards. It isn't any kind of bug that can be spotted with a microscope or banished with a sprayer. The worst enemy of the farmers of America is the crooked farmer who puts out his product under false pretenses and thinks that his shortsighted tricks are putting him ahead of the game. He fouls the whole nest for himself and every man in his particular line of production."

Collective or coöperative selling has been found profitable. The orange and lemon growers of California, the apple growers of Oregon, the cauliflower growers of Long Island, and others combine to send their produce to market in carload lots. This enables them by their agents to learn of the best markets and to ship their goods at the best time and in the best manner. The practice of growing the crop best adapted for the locality instead of scattering their efforts to produce many crops teaches them to be specialists in the growing and marketing of that particular crop. Laws such as the Sulzer apple barrel bill and others prescribing the uniform capacity of containers help towards uniform and better prices.

The departments of agriculture of the several states should issue bulletins giving information to the farmers and shippers of the condition of the market and the best methods of packing and shipping their goods. Every such department also should have a bureau of standards and tests in which farmers, shippers and manufacturers of foodstuffs eould register and receive a license permitting them to label their 
packages with a statement of their quantity, quality and grade of the contents of the package and the registry number and name of the sender. Fraud in such statement should be punished by a fine and subsequent fraud by cancellation of the license. Registered goods would command better prices than goods sold as miscellaneous without registry. All of the methods here enumerated for the farmer tend to better the quality and condition in which the goods come to market and to establish that confidence between buyer and seller which is essential to all good business.

After the producer has done everything possible for good marketing, there comes the question of transportation. Car shortage at periods of greatest need and lack of terminal facilities in the larger cities result in spoilage, delays and consequent loss. The lack of terminal facilities sometimes results in car shortage because of the impossibility of getting cars in and out of the markets. The rates charged by the railroads, steamships and steamboats are reasonable, as a rule. Freight rates do not add much to the cost of food products to the consumer. For example, the average distance grain is carried on railroads in the United States is from 220 to 225 miles, and the average rate of freight is 4 cents per bushel. The rate on wheat from Kansas City to New York, a distance of over 1,000 miles, is about 14.5 cents per bushel, or 65 cents for enough wheat for a barrel of flour. The freight rate therefore, on the wheat or flour forming a loaf of bread would not exceed one-fourth of a cent a loaf. Celery carried in refrigerator cars from Florida to New York would amount to about $65 \frac{1}{2}$ cents or from one-eighth to one quarter its retail price.

Freights by water are cheaper. Mr. S. A. Thompson of Washington, sets this forth clearly:

Suppose you had a ton of freight to ship and a dollar to spend in shipping it. How far will the dollar carry the ton? By horse and wagon, a little over 4 miles; by English steam truck, 20 miles; by rail at the average rate for United States railways, 133 miles; at the rate of a group of selected railways, 200 miles; in the Erie Canal, 333 miles; on the European canals, 500 miles; by lake at the average rate through the "Soo Canal" in 1911, 1,500 miles; while at the rate at which coal is carried both on the Great Lakes and on the Ohio and Mississippi Rivers, the ton of freight can be shipped 30 miles for a cent, 300 miles for a dime, 3000 miles for a dollar."

In the whole distributing system the greatest loss is in the cities. The American cities have not given the subject of marketing any 
attention. They have left the trade to take care of itself and to rely upon the uncoördinated efforts of the various transit lines which have looked only to the upbuilding of their own particular traffic. The result is a total lack of modern marketing facilities in the big cities. For example, in New York, food products are brought in by rail or steamship or steamboat at various docks along the waterfront or railroad yards extending from the Battery to 42nd Street on the lower west side of the city. They must be trucked through the crowded streets to their places of destination and often handled three or four times before they come into the hands of the retailer. Perishable and semiperishable products often are taken out of cooled cars and exposed to the sun or cold for hours at a time. Because of lack of storing facilities, the whole daily trade in perishable products must be finished in a few hours so that endless confusion and poor prices for much of the supply result. Many complaints have been made by the shippers that the returns from the sales of the goods have been much less than the actual selling prices, and that sometimes, even when the commission man is honest, his salesmen have reported cash sales for much lower prices than the true prices, and have pocketed the difference. This has a tendency to bring the honest commission man into disrepute, as well as the dishonest, and hurts the whole trade. A law should be passed by the state requiring all commission men to take out licenses at a nominal fee, such as $\$ 10$, for the honest conduct of their business. Any fraud should be punished by fine and a second or third offense should result in a loss of the license. This would make for better trade practices and increase the confidence between seller and buyer, especially if coupled with a similar licensing of shippers.

The cities should treat marketing as a very important governmental function and provide the railroads and other transit lines with proper facilities for their business. Wholesale terminal markets should be built on the waterfront if possible, into which all railroads could run their cars without breaking bulk. Such markets should have cold storage rooms into which the contents of refrigerated or cooled cars could be transferred without delay. Broad streets should be made so that trucks would not be delayed in taking away the goods. Auctioneers, licensed by the city should be given the right to sell all goods which the shipper desired sold at auction, so that goods could be consigned directly to the market and sold without intermediate handling. Daily market reports should be issued stating the kinds and quantity 
and prices of goods in the market, so that the retailer and the housewife could be informed of the state of the market.

The wholesale market may be termed the primary market. Various forms of retailing or secondary marketing are advocated, such as coöperative stores, chain stores and the like, but it is evident that many of the high prices now charged by the retailer are due to the fact that he cannot buy his goods at reasonable prices. He must charge high prices in order to live. Lack of wholesale marketing facilities and lack of knowledge on the part of the housewife combine to make high prices possible. Gluts in the wholesale markets seldom are known throughout the city, so they result only in waste. High prices in the city mean low prices eventually in the country. They result in under-consumption of food products and consequent hardship to the people in the cities and loss to the farmer because of lack of demand for all he raises. Even if he succeeds in selling part of his crop at good prices, the balance left on his hands often makes the whole crop unprofitable. A steady demand at even low prices makes for better business than alternate high and low prices, as it enables the farmer to calculate upon a uniform business.

Meats are likely to remain high in price for the simple reason that the number of consumers in the United States is increasing, while the number of meat animals is decreasing. In 1910 less corn was grown in the United States than 1900. Of wheat, although the acreage was increased, less than 4 per cent more wheat was produced, and less than 7 per cent more oats. This means that the food for cattle, hogs and poultry, as well as for human beings, increased in cost. The output of corn, oats, barley and cotton in 1910 was less than in 1900. The average yield of corn per acre in 1910 was only 26 bushels. The output of wheat per acre increased somewhat because some poor wheat land was withdrawn from cultivation. During the period from 1900 to 1910 the population increased twenty-one per cent, so we have a decreased production and an increased consumption, with resulting higher prices. This is shown by the fact that while the per capita supply decreased, the prices paid to the farmer increased from 34 per cent in some cases to 83 per cent in others. The rise in meat prices was inevitable, as there were less meat animals in 1912 than in 1900 in the United States. The receipts of the market from March, 1911, to March, 1912 , show a decrease of 121,600 cattle, and calves, 300,000 hogs, 225,000 sheep, or a total decrease of 646,600 meat animals, amounting 
to a shortage of $200,000,000$ pounds. The abolition of the tariff of 25 per cent on the mutton of New Zealand and the beef of Argentina and Brazil may help to lower the prices of meats.

The high prices of meats are the result of forces curtailing the supply, which cannot be evaded, but such forces do not prevail over farm products. The Malthusian theory that population increases faster than the means of subsistence has practical disproof when intensive farming and scientific methods of distribution furnish practically limitless supplies. The shortage of supplies and the high prices of farm products are the result more of lack of distributing facilities than anything else. In short, what is needed to reduce the prices of farm products to the consumer, is the education of the farmer in the selection of his market and the intelligent and honest packing and grading of his goods, and proper wholesale terminal markets in the cities. 